\title{
REFORMULASI PENDIDIKAN PANCASILA DAN KEWARGANEGARAAN UNTUK MENGUATKAN NASIONALISME WARGA NEGARA MUDA DI WILAYAH PERBATASAN
}

\author{
Sutiyono ${ }^{1,}$ Suharno ${ }^{2}$ \\ Pendidikan Pancasila dan Kewargangearaan, PPS UNY ${ }^{1,}$ \\ Pendidikan Pancasila dan Kewargangearaan, PPS UNY ${ }^{2}$ \\ sutiyonoa362@gmail.com ${ }^{1}$, suharno@uny.ac.id ${ }^{2}$
}

Naskah diterima: 11/10/2017 revisi: 03/06/2018 disetujui: 23/04/2018

\begin{abstract}
Abstrak
Indonesia sebagai negara kepulauan, memiliki beberapa daerah perbatasan yang rentan akibat globalisasi. Tingginya akses mobilisasi baik barang, jasa, maupun perseorangan membuat daerah perbatasan rentan terjadinya degradasi nasionalisme. Pihak yang sangat rentan akibat fenomena ini adalah warga negara muda. Salah satu upaya yang dapat ditempuh untuk menguatkan nasionalisme melalui pendidikan formal. Salah satu mata pelajaran yang memiliki tujuan untuk menumbuhkan nasionalisme pada warga negara muda adalah Pendidikan Pancasila dan Kewarganegaraan. Tujuan penulisan ini untuk mereformulasikan Pendidikan Pancasila dan Kewarganegaraan untuk menguatkan nasionalisme warga negara muda di wilayah perbatasan. Metode penulisan yang digunakan dalam menyusun karya tulis ini yaitu library research dan kajian hasil penelitian mengenai penguatan karakter nasionalisme melalui pembelajaran PPKn. Hasil pembahasan dimaksudkan reformulasi PPKn mengarahkan peserta didik untuk memiliki kompetensi "act locally and think globally". Kompetensi ini untuk melestarikan nilai-nilai berpangkal pada kualitas ke-Indonesiaan dengan cara pandang internasional. Melalui reformasi PPKn akan mendorong penguatan nasionalisme warga negara muda di wilayah perbatasan.
\end{abstract}

Kata Kunci: Nasionalisme, PPKn, Warga Negara Muda

\section{THE REFORMULATION OF PANCASILA AND CIVIC EDUCATION TO IMPROVE YOUNG CITIZENS NATIONALSM IN THE BORDER REGION}

\begin{abstract}
Indonesia as an archipelagic country, has several border areas that are vulnerable due to globalization. The high access to mobilization of goods, services, and individuals makes the border areas vulnerable to nationalism degradation. A very vulnerable party to this phenomenon is a young citizen. One of the efforts that can be taken to strengthen nationalism through formal education. One of the subjects that have a goal to foster nationalism among young citizens is Pancasila and Citizenship Education. The purpose of this paper is to reformulate the Pancasila and Citizenship Education to strengthen the nationalism of young citizens in the border region. Writing methods used in composing this paper is the library research and study results of research on strengthening the character of nationalism through learning PPKn. The results of the discussion meant that PPKn reformulation leads learners to have "act locally and think globally" competencies. This competence to preserve the values stems from the quality of Indonesianness with an international perspective. Through PPKn reform will encourage the strengthening of the nationalism of young citizens in the border region.
\end{abstract}




\section{PENDAHULUAN}

Indonesia merupakan negara kepulauan yang terdiri dari beberapa pulau dengan keberagaman bahasa, suku, ras, dan budaya. Indonesia sebagai negara kepulauan telah ditetapkan pada tanggal 13 Desember 1957 oleh Perdana Menteri Indonesia Djuanda Kartawidjaja melalui suatu deklarasi yang dinamakan persis seperti pencetusnya yaitu Deklarasi Djuanda (Darmaputra, 2009:12). Konsekuensi sebagai negara kepulauan, Indonesia memiliki beberapa daerah perbatasan secara daratan (kontinen) maupun batas lautan (maritim). Kekayaan alam dan budaya Indonesia tidak kalah banyaknya dengan jumlah pulaunya. Karakteristik yang berbeda baik secara geografis, sosiokultural, dan suku, ras, serta agama menjadikan Indonesia negara multikultural terbesar di dunia (Zarbaliyev, 2016). Hal ini juga bisa menjadi pemicu konflik antarsuku, ras, golongan, bahkan agama di masingmasing pulau karena perberbedaannya seperti catatan kelam dipenghujung pemerintahan rezim Soeharto (Budiman, 2010). Oleh karena itu, perlu adanya penguatan tentang rasa mencintai dan bangga sebagai bangsa Indonesia dalam rangka memperkuat persatuan dan kesatuan. Pemahaman tentang mencintai dan mempertahankan Negara Kesatuan Republik Indonesia disebut sebagai nasionalisme.

Nasionalisme di perbatasan sangat penting untuk menjaga persatuan dan kesatuan Negara Kesatuan Republik Indonesia. Wilayah perbatasan merupakan lokasi yang sangat rentan lunturnya perasaan dan sikap nasionalisme. Hal ini disebabkan letak wilayah yang sangat jauh dengan pusat pemerintahan atau bisa dikatakan wilayah yang paling dekat dengan negara tetangga. Disisi lain, globalisasi juga mempengaruhi degradasi nasionalisme akibat mobilitas yang tinggi dalam berinteraksi dengan warga negara yang memiliki perbedaan kewarganegaraan. Dampaknya, tidak sedikit fenomena yang mempengaruhi penggunaan bahasa multilingual, mata uang ganda, konsumsi produk dari negara lain berimbas pada goyahnya rasa kebanggaan terhadap negeri sendiri (Dedes, 2015:2). Di sinilah, pentingnya memupuk rasa nasionalisme pada masyarakat perbatasan yang bukan tidak mungkin terjadi pengikisan nasionalisme akibat kedekatan baik secara geografis, sosio-kultural, dan interaksi dengan warga negara lain. Warga negara muda menjadi salah satu perhatian serius akan efek dari degradasi nasionalisme di wilayah perbatsan. Warga negara muda merupakan aset bangsa yang akan meneruskan nasib bangsa dan negara kedepannya. Salah satu cara yang bisa ditempuh dalam menumbuhkan nasionalisme pada warga negara muda melalui jalur pendidikan.

Pendidikan menjadi faktor penting penguatan karakter bangsa Indonesia terutama pada generasi muda di wilayah perbatasan. Sekolah memiliki kewajiban untuk memelihara dan menguatkan nilainilai nasionalisme peserta didiknya demi terwujudnya pembinaan yang berkelanjutan dalam rangka menguatkan nasionalisme di persekolahan. Berdasarkan Pasal 1 Nomor 2 Undang-Undang Nomor 20 Tahun 2003 tentang Sistem Pendidikan Nasional yang berbunyi "Pendidikan Nasional adalah pendidikan yang berdasarkan Pancasila dan Undang-Undang Dasar Negara Republik Indonesia Tahun 1945 yang berakar pada nilai-nilai agama, kebudayaan nasional Indonesia, dan tanggap terhadap tuntutan zaman". Pendidikan persekolahan yang secara khusus memiliki tanggung jawab besar dalam pembinaan nasionalisme warga negara muda. Mata pelajaran yang memiliki tujuan untuk membentuk warga negara yang baik dan cerdas berdasarkan kualitas keIndonesiaan adalah Pendidikan Pancasila dan Kewarganegaraan. Komponen utama yang diajarkan dalam PPKn kepada peserta didik mencakup pengetahuan 
kewarganegaraan (civic knowledge), keterampilan kewarganegaraan (civic skills), dan watak kewarganegaraan (civic disposition). Komponen tersebut, menjadi indikator utama dalam menguatkan nasionalisme warga negara muda khususnya di wilayah perbatasan. Berdasarkan data nasionalisme di perbatasan tersebut, PPKn perlu diformulasikan kembali yang secara intensif menguatkan nasionalisme warga negara muda di wilayah perbatasan Indonesia. Tulisan ini mencoba memberikan gambaran baru tentang reformulasi PPKn untuk menumbuhkan, menanamkan, dan menguatkan nasionalisme warga negara muda di wilayah Perbatasan.

\section{METODE}

Metode penulisan artikel ini menggunakan metode library research. Metode ini digunakan untuk menjawab studi pendahuluan (prelinmary research) untuk memahami lebih mendalam gejala baru yang tengah berkembang di lapangan atau dalam masyarakat (Zed, 2004). Selanjutnya, menurut Zed (2004:54), menjelaskan bahwa riset kepustakaan adalah serangkaian kegiatan yang berkenaan metode pengumpulan data pustaka, membaca dan mencatat serta mengolah bahan penelitian.

\section{Waktu dan Tempat Penelitian}

Proses penyusunan artikel ini dimulai dari anggapan yang didasarkan dari data-data sesuai dengan topik pembahasan. Berdasarakan anggapan tersebut, selanjutnya dilakukan tindak lanjut dengan mengelompokkan data secara sistematis untuk memberikan penjelasan dari anggapan tersebut. Setelah itu, data yang telah dikumpulkan secara sistematis dianalisis dan ditafsirkan untuk menjelaskan fenomena dengan alur pikir ilmiah. Dengan demikian, akan menciptakan sebuah solusi awal untuk menjawab persoalan yang diangkat dalam artikel ini.

\section{Target/Subjek Penelitian}

Beberapa jenis literatur utama yang digunakan terdiri atas buku-buku dan artikel jurnal mengenai Pendidikan Pancasila dan Kewarganegaraan, nasionalisme, warga negara muda, dan wilayah perbatasan serta peraturan pemerintah mengenai pengelolaan perbatasan dan undang-undang tentang pendidikan nasional dan wilauah perbatasan.

\section{Prosedur}

Penelitian ini dimulai dengan pengumpulan data yang dilakukan dengan studi literasi, yaitu mengidentifikasi berbagai referensi yang terkait dengan judul artikel. Data atau informasi tersebut, didapatkan dari literatur yang dapat dipertanggungjawabkan. Selanjutnya, disusun berdasarkan hasil studi dari berbagai literatur yang memiliki tenggang waktu yang relatif berbeda, sehingga terkait satu sama lain dan sesuai dengan tema yang dibahas.

\section{Data Instrumen dan Teknik Pengumpulan Data}

Data yang digunakan berasal dari artikel jurnal dan literatur ilmiah lainnya yang bersifat tekstual dengan berpijak pada esensi tematik terkait satu sama lain yang dikemukakan oleh ahli atau pakar memiliki korelasi dengan pembahasan. Sumber data lebih banyak dari data collection, yaitu dokumen pribadi yang berupa artikel hasil penelitian yang telah ter-publish dari online maupun offline. Data online berupa artikel hasil penelitian, sedangkan data offline berasal dari buku-buku primer dan peraturan yang berkaitan dengan topik pembahasan artikel ini.

Teknik pengumpulan data menggunakan teknik dokumentasi, melakukan coding data dari buku-buku, jurnal, dan literatur terkait yang memiliki korelasi dengan artikel ini. Setelahnya, akan diterjemahkan kembali menjadi transkrip, catatan, dan sebagainya untuk memperoleh kevalidtan data.

\section{Teknik Analisis Data}

Analisis data dilakukan secara induktif, yang di dalamnya terdiri dari dua tahap yaitu proses reduksi data dan penyajian data. Reduksi data bertujuan 
untuk penulis lebih mudah dalam memilih data yang valid, sedangkan penyajian data agar dimungkinkan penarikan simpulan. Penarikan simpulan didapatkan sesudah merujuk tujuan penulisan, analisis dan sintesis. Simpulan juga memperhatikan penyajian data dari pembahasan yang ditarik merepresentasikam pokok-pokok bahasan dalam karya tulis serta didukung dengan saran praktis sebagai rekomendasi selanjutnya. Penarikan simpulan didapatkan sesudah merujuk rumusan masalah, tujuan penulisan, analisis dan sintesis. Simpulan juga memperhatikan penyajian data dari pembahasan yang ditarik merepresentasikan pokok-pokok bahasan dalam karya tulis serta didukung dengan saran praktis sebagai rekomendasi selanjutnya.

\section{HASIL DAN PEMBAHASAN Kajian Nasionalisme}

Renan (Hutchinson dan Smith, 1994: 17) mendefinisikan bahwa "a nation is a soul, a spiritual prinsiple....a grand solidarity". Istilah "nasion" pada dasarnya merupakan satu jiwa, suatu azas spiritual, suatu solidaritas yang besar. Kesemuanya ini dibentuk oleh kesadaran tentang hidup bersama. Hal ini bisa jadi tersalurkan dengan narasi sejarah tentang kejayaan atau penderitaan masa lalu. Kemudian, narasi kejayaan tersebut diharapkan memunculkan suatu rasa kebanggaan. Sedangkan, narasi penderitaan masa lalu, diharapkan dapat membangkitkan suatu "kesediaan untuk berkorban". Di sinilah basis moral solidaritas yang besar itu mewujud.

Kajian mengenai "nasion" ditunjukkan berbeda oleh Joseph Stalin (dalam Budiawan, 2017: 3), mendefinisikan "nasion" sebagai "a hostorically constitude, stable community of people, formed on the basis of a common language, territory, economic life, and psychological make-up manifested in a common culture" (Hutchinson dan Smith, 1994: 18-19). "Nation" merupakan suatu komunitas yang stabil, yang terbentuk secara historis atas dasar kesamaan bahasa, wilayah, kehidupan ekonomi, dan karakter psikologis sebagaimana termanifestasikan dalam kebudayaan bersama. Stalin bahkan menekankan bahwa hanya bila semua ciri ini hadir bersama, maka disitulah terbentuk sebuah "nasion". Stalin, lebih melihat suatu kesamaan dari segi lahiriah bukan termasuk batiniah.

Berbeda lagi kajian konsep "nasion" yang disampaikan oleh Max Webber (dalam Budiawan, 2017: 4) bahwa "nation is a community sentiment....manifest is self in a state of its own: hence...it normally tends to produce a state of its own". "Nasion" pada dasarnya merupakan sutau komunitas pertalian ikatan-ikatan emosional, yang mewujudkan diri dengan cara sendiri oleh tujuan politik bersama. Tujuan politik bersama ini dibangun dari memori yang sama. Hal ini berarti bahwa apa yang disampaikan oleh Stalin tentang kesamaan etnis/budaya/bahasa tidak ada korelasinya dengan pembentukan sebuah "nasion". Artinya tidak selamanya kesamaan etnis/budaya/bahasa tidak dengan sendirinya mendasar sebuah pembentukan "nasion", sebaliknya, perbedaan etnis/budaya/bahasa tidak selalu menghalangi pembentukan sebuah "nasion". Dengan demikian, Rogers Brubaker (2004: 116) menyampaikan bahwa pemikiran Weber mengenai "nasion" dan "nasionalisme" bahwa "nasion" bukanlah konsep "a category of analysis", melainkan "a category of practice". Sebab, nattionhood pada dasarnya bukanlah fakta etnodemografis atau etnokultural, melainkan klaim politis. Lebih tepatnya adalah klaim atas loyalitas orang dengan kepedulian, perhatian dan solidaritasnya. Sebagaimana yang disampaikan oleh Anthonny Giddens (1985: 38) mendefinisikan bahwa "nasion" hanya mungkin ada jika "state" memiliki jangkauan administrasi atau pemerintahan yang padu atas teritori yang diklaim sebagai wilayah kedaulatannya. Gidden meyakini bahwa negara-bangsa merupakan seperangkat bentuk-bentuk kelembagaan 
tata kelola, yaitu pemerintahan, wilayah, dan kedaulatan. Lantas, kebanyakan "nation" dan "state" sering digunakan secara bergantian dan keduannya dianggap relatif sama.

Connor mencoba menjelaskan mengenai kemunculan "nation" dan "state" yang berawal dari Revolusi Prancis, ketika terjadi transformasi dari L'etat c'est moi (negara adalah saya/raja) ke L'etat c'est le peuple (negara adalah rakyat). Dengan peristiwa inilah, "state" dituntut untuk mengejawantahkan atau menjadi pelayan kepentingan publik. Bermula dari sinilah konsep "nation" dan "state" hampir sama. Pada konteks inilah istilah nasionalisme muncul sebagai ideologi yang menuntut loyalitas rakyat kepada "nation", mudah melenceng menjadi loyal kepada "state".

Dewasa ini, muncul fasisme dan totalitarianisme, yakni satu bentuk nasionalisme ekstrim, yang menuntut loyalitas setiap individu atau warga negara secara total kepada "negara", yang tidak lain adalah rezim yang berkuasa. Hal ini juga tidak lepas dari istilah yang identik antara "nation" dan "state". Munculnya fasisme dan totalitarianisme, menjadikan "state" bukan lagi sebagai pengawal, tetapi justru penyandera dari pada konsep "nasion". Celakanya, proses penyanderaan "nasion" dilakukan secara demokratis, sehingga seperti "legitimate". Berdasarkan penggabungan keduanya yaitu "nationstate" munculah suatu ideologi yang menopang dan menunjangnya disebut sebagai nasionalisme.

Elie Kedourie (Kitromilides, 2005) menyampaikan bahwa nasionalisme merupakan doktrin yang menyeluruh dan membimbing serta mengarahkan orang menuju suatu model bernegara yang spesifik (a distinctive style of politics). Hal ini didasarkan pada pandangan bahwa manusia adalah makhluk yang memiliki otonom (self-determinism) yang memiliki pilihan menentukan sejarahnya sendiri. Oleh karena itu, konsep ini melahirkan apa yang disebut sebagai patriotisme dan xenofobia. Patriotisme merupakan suatu bentuk kesetiaan kepada negara, kelompok, atau institusi yang menangunginya. Sedangkan, xenofobia merupakan ketidaksukaan kepada yang asing atau diluar kelompoknya. Maka, nasionalisme ini melahirkan dua konsep baru yakni sentimen berwajah ke dalam dan sentimen berwajah ke luar.

Metode berpikir Kedourie yang seperti Hegelian, ditentang oleh Ernest Gellner (Keith Breen and Shane O'Neil, 2010: 24). Gellner menyampaikan bahwa sejarah tidak dibentuk dari sebuah pikiran atau ide, akan tetapi idelah yang dibentuk oleh sejarah atau setidaknya ide tidak pernah otonom pada dirinya sendiri. Gellner meyakini bahwa sejarahlah yang menghasilkan ide tentang "nasion" merupakan fenomena "modernisasi". Konsep modernisasi ini lebih mempercepat adanya pelipatgandaan hasil daripada sejarah. Gagasan nasionalisme yang berasal dari elitis agar menjadi populis, maka nasionalisme mengeklaim bahwa nasionalime berakar dari budaya-budaya rakyat (folk culture). Bila ditinjau sudut pandang demikian, maka nasionalisme seperti menipu diri sendiri. Sifat selfdeceptive (menipu diri sendiri) nasionalisme nyaris tidak dikenali karena negara dengan segala perangkat kelembagaannya terusmenerus memproduksi dan mereproduksi loyalitas pada komunitas yang lebih besar dan luas daripada komunitas tribal, lokal, dan sebagainya, tetapi lebih sempit daripada komunitas peradaban yang biasanya terkait imperium beserta sistem religinya. Dengan demikian, kedudukan "nasion" merupakan sesuatu yang ditemu-ciptakan (invented), bukan sesuatu yang diberi (given). Gagasan ini didukung oleh beberap ahli berikutnya seperti Tom Nair, Eric Hobsbawn, Paul R. Brass, dan Bennedict Anderson. Paul R Brass mencoba merekonsiliasi antara pendekatan primordialis dan instrumentalis. Hasilnya, nasionalisme menurut Paul $\mathrm{R}$ Brass merupakan produk konstestasi 
antarkelompok elit dalam suatu masyarakat. Masing-masing kelompok elit mencoba menyeleksi aspek-aspek tertentu dari budaya kelompok tersebut. Aspek budaya yang diseleksi hanya yang dapat dianggap mempersatukan semua unsur dalam kelompok dan berguna untuk mempromosikan apa yang berguna bagi kepentingan kelompok tersebut.

Benedict Anderson (1999: 5) juga menyampaikan konsep tentang imagined community (komunitas yang dibayangkan) sebagai refleksi nasionalisme. Benedict (1999:6) menyampaikan bahwa "nation is imagined political community and imagined as both inherently limited and sovereign" (Nasion adalah komunitas politik yang dibayangkan dan di dalam dirinya dibayangkan baik secara terbatas maupun berdaulat). Komunitas membayangkan anggotanya bahkan tidak pernah ketemu secara langsung, namun di dalam diri mereka menggema perasaan senasib sepenanggungan. Bahkan dengan komunitas terbayangkan tersebut, sampai rela berkorban jiwa untuk nasionnya. Komunitas yang dibayangkan atau imagined community sangat terbatas. Hal ini disampaikan oleh Anderson bahwa sekalipun besar komunitasnya akan tetap terbatas. Pada akhirnyam nasion itu dibayangkan sebagai komunitas, sebab, kendati di dalamnya terdapat ketidaksetaraan dan mungkin ekploitas (satu kelompok atas kelompok lainnya), nasion senantiasa dipahami sebagai persaudaraan horisontal yang mendalam.

Anderson juga menyampaikan tentang kondisi historis yang menentukan sekulerisasi. Misalnya tentang penggunaan bahasa cetak dalam keseharian. Waktu dulu bahasa yang digunakan telah dicetak dengan dibubuhi sebuah pesan. Oleh sebab para penutur beragam dialek bahasa Jerman, Perancis, Inggris, yang sangat beragam, kemudian disepakati dalam satu dialek. Selain itu, dari segi produk budaya yang dibentuk menjadi faktor penting untuk melahirkan ide subjektif tentang nasion. Artinya klaim tentang sejarah apa yang dihasilnya mempengaruhi seberapa besar muncuknya nasion dalam suatu komunitas.

Berdasarkan data sejarah mengenai nasion dan nasionalisme, terlihat banyak beberapa ilmuan memiliki pemaknaan yang berbeda mengenai nasionalisme. Hal ini disebabkan karena antara ilmuan yang satu dengan lainnya mengambil suatu sudut pandangan yang berbeda. Nasionalisme merupakan paham untuk menumbuhkan sikap cinta terhadap tanah air yang didasarkan pada perasaan senasib, kemudian bergabung menjadi satu untuk bersamasama mempertahankan dan loyal terhadap bangsa dan negara (Novita, 2014: 4). Dengan kata lain, nasionalisme merupakan suatu pengikat persatuan bangsa untuk suatu tujuan yang sama. Menurut Syarbaini (2010: 65) nasionalisme merupakan suatu jiwa yang dilandasi rasa kesetiaan yang tinggi atau total diabdikan untuk bangsa atau negara. Snyder (1954: 148), juga menyampaikan bahwa nasionalisme merupakan suatu pengikat adanya independensi dan kesatuan bangsa.

Setelah melihat dari definisi yang beragam, banyak beberapa ilmuan yang mengambil beberapa simpulan tentang nilai indikator dari nasionalisme. Siti Munawaroh (2015: 138) menjelaskan bahwa nasionalisme dapat dilihat dari beberapa aktivitas diantaranya: (1) rasa cinta terhadap tanah air dan komponen di dalamnya; (2) tingkat partisipasi dalam pembangunan; (3) berperilaku adil; (4) berorientasi pada masa depan; (5) prestatif, mandiri, dan bertanggungjawan; (6) siap bekerjasama ditingkat lokal, nasional, dan internasional. Di sisi lain, Trisandi (2013: 29) juga menyampaikan bahwa perilaku yang mencerminkan nilai-nilai nasionalisme diantaranya: (1) perasaan senang dan bangga sebagai bangsa Indonesia; (2) mampu menghargai jasa-jasa para pahlawan yang telah memperjuangkan negara Indonesia; (3) memiliki jiwa penolong yang 
tinggi; (4) giat belajar pada bidangnya; (5) mencintai produk dalam negeri; (6) kepedulian sosial; (7) memiliki jiwa toleran yang tinggi atau apresiatif; (8) tidak memaksakan kehendak pribadi dalam musyawarah umum.

Pada era globalisasi ini, setidaknya nasionalisme merupakan suatu alat yang bisa membentengi atau memfilter beberapa mobilisasi kebudayaan yang kurang tepat bagi budaya yang asli dari negara tertentu. Aman (2011: 141) menyampaikan bahwa di era global negara harus berperan dalam menguatkan nilai-nilai nasionalisme pada warga negara agar tetap loyalitas dan memiliki jiwa mengabdi pada bangsa dan negara. Sikap cinta tanah air dapat tergambarkan pada kepedulian terhadap isu isu kewarganegaraan, menjaga persatuan dan kesatuan bangsa, setia mencintai produk buatan dalam negeri, rela berkorban terhadap bangsa dan negara di atas kepentingan pribadi, mengharumkan nama bangsa melalui prestasi atau sebuah karya dan memfilter budaya yang masuk akibat globalisasi (Trisandi, 2013: 27). Dengan demikian, nasionalisme adalah sebuah citacita yang ingin memberi batas antara bangsa sendiri dan bangsa lain. Nasionalisme secara umum merupakan paham kebangsaan yang didasari dari nasib, semangat, dan cita-cita yang sama dalam suatu negara. Nasionalisme diperlukan untuk memperkokoh persatuan dan keutuhan suatu negara.

Pada konteks Indonesia, Aman (2011: 141) juga menyampaikan bahwa beberapa indikator nilai-nilai nasionalisme diantaranya: (1) bangsa menjadi bangsa Indonesia; (2) cinta terhadap bangsa dan negara; (3) rela berkorban demi bangsa; (4) menerima kemajemukan atau memiliki jiwa toleran; (5) bangga terhadap kekayaan budaya Indonesia; (7) memprioritaskan kepentingan umum.

\section{Konsep Wilayah Perbatasan}

Ditinjau dari suku katanya, wilayah perbatasan terdiri dari wilayah dan perbatasan yang memiliki makna yang berbeda. Pengertian perbatasan secara umum diungkatkan oleh Darmaputra (2009:3), perbatasan adalah sebuah garis demarkasi antara dua negara yang berdaulat. Pada awalnya perbatasan sebuah negara atau state's border dibentuk dengan lahirnya negara. Padahal sebelum lahirnya negara, penduduk yang menempati wilayah cenderung mengabaikan sebuah perbedaan, tetapi tidak jarang berdomisili yang berasal dari etnis yang idetik sama. Akan tetapi, lahirnya negara membuat penduduk harus memiliki sebuah kewarganegaraan yang ditentukan oleh negaranya masing-masing dan cenderung berbeda. Sedangkan, pembahasan mengenai wilayah cenderung mengarah pada tempat yang tidak bisa ubah keberadaanya bersama sejarah dan hukumnya.

Perbatasan merupakan aspek penting oleh suatu negara yang dihasilkan melalui perjanjian Wesphalia Tahun 1618. Hal ini dikarenakan wilayah perbatasan merupakan wilayah yang menentukan dimana suatu otoritas negara diimplementasikan sekaligus menjadi pembatas sampai mana otoritas negara itu berakhir. Selain itu, perbatasan juga merupakan aspek penting dimana kedaulatan negara bersinggungan langsung dengan kedaulatan negara lain. Fakta demikian, merupakan hal yang wajar dialami oleh suatu negara bangsa atau nation-state. Wesphalia terproliferasi diseluruh dunia, sehingga hampir tidak terdapat wilayah yang tidak berada dalam otoritas suatu negara.

Konsep perbatasan berkaitan dengan tiga pengertian utama yang mencakup terminologi border, bounday, dan frontier. Di samping kata "border", setiap studi mengenai wilayah perbatasan akan bersinggungan dengan istilah "boundary" dan "frontier". Haba (2010: 5) menyampaikan border adalah garis batas internasional ketika perbatasan dilihat 
sebagai sebuah zona, maka hal ini disebut dengan wilayah perbatasan (borderland). Kemudian, tiga terminologi yang merujuk ke wilayah perbatasan itu, maka terminologi frontier juga bertumpang tindih dengan garis batas, yang berhubungan dengan zona atau titik temu dengan atau tanpa sebuah wilayah negara (boundary). Dengan demikian, perbatasan diartikan sebagai sebuah entitas fisik dengan perwujudan relasi timbal balik dan saling bergantungan secara sosial yang cukup intens antara intergroup members dan outgroup members (Haba, 2010: 6).

Di Indonesia, fenomena wilayah perbatasan suatu negara dapat terlihat dari bentangan pulau-pulau yang berhimpitan dengan negara lain baik secara kontinen dan maritim. Wilayah perbatasan Indonesia dapat dilihat dari batas negara yang terdiri dari sepuluh negara seperti Australia, Papua Nugini, Malaysia, Singapura, Filiphina, Thailand, Vietnam, Timor Leste, India, dan sebuah pulau. Negara yang berbatasan dengan Indonesia melalui darat atau kontinen adalah Papua Nugini, Malaysia, dan Timor Leste. Selain ketiga negara tersebut, wilayah perbatasan Indonesia dibatasi oleh laut atau maritim. Dengan demikian, Indonesia sebagai negara yang berdaulat harus menjaga dan memelihara perbatasannya.

Pengelolaan wilayah perbatasan di Indonesia diatur dalam Undang-undang Nomor 43 Tahun 2008 tentang Wilayah Negara dan PP Nomor 12 Tahun 2010 tentang Badan Nasional Pengelola Perbatasan (BNPP). Kedua peraturan ini, mengandung konsekuensi pada pembentukan Badan Pengelola Perbatasan baik ditingkat daerah maupun nasional. Sehingga, BNPP merupakan institusi terdepan yang mengelola wilayah perbatasan dengan tugas mengkoordikasikan dan pelaksanaan yang bersifat koordinatif operasional. Akan tetapi, tidak semua persoalan yang terjadi di wilayah perbatasan menjadi tanggungjawab BNPP, perlu adanya dukungan berbagai sektor untuk tetap menjaga dan memlihara wilayah perbatasan Indonesia baik dari segir maritim dan kontinen.

Patut diakui bahwa garda depan negara bukan saja terhantung pada aparat keamanan, tetapi warga negara yang merupakan pagar betis utama di wilayah perbatasan. Diviasi perilaku menjadi tidak nasionalis bukan karena tidak mencintai Negara Kesatuan Republik Indonesia, tetapi ada pertimbangan yang jauh lebih esensial yakni kualitas kehidupan warga negara Indonesia yang rendah kalau dibanding dengan negara lainnya (Noveria, 2016: 237). Dengan harapan tetap stabil dan perpeliharanya perasaan dan perilaku nasionalis dalam masyarakat perbatasan, maka diperlukan suatu penguatan dan pembinaan nasionalisme di daerah perbatasan. Pertimbangan lain yaitu wilayah perbatasan merupakan wilayah yang memiliki potensi strategis diantaranya: (1) wilayah perbatasan memiliki pengaruh terhadap kedaulatan negara; (2) wilayah perbatsan merupakan pendorong peningkatan kesejahteraan sosial ekonomi masyarakat; (3) wilayah perbatasan memiliki keterkaitan untuk saling mempengaruhi wilayah antarnegara; (4) wilayah perbatasan memiliki pengaruh terhadap pertahanan dan keamanan (Poetranto, 2008).

\section{Kajian Warga Negara Muda}

Sebelum menjelaskan mengenai warga negara muda, akan dikaji terlebih dahulu mengenai warga negara. Secara umum, warga negara merupakan seseorang yang menempati suatu negara yang memiliki status hukum yang tetap, diakui secara yuridis formal (KTS) dan memiliki hak serta kewajiban yang diperuntukan bagi negara tersebut. Ditinjau dari status kewarganegaraannya, keberadaan orangorang dalam wilayah suatu negara dapat dikelompokkan menjadi 2 (dua), yaitu: 1) orang yang berstatus sebagai warga negara, 
dan 2) orang yang berstatus sebagai orang asing.

Tijan (2009: 14-15), menjelaskan bahwa warga negara adalah anggota negara, yaitu anggota dari suatu organisasi kekuasaan yang dinamai negara. Beberapa istilah yang sering digunakan untuk menyebut warga negara adalah citizen, national, subject, onderdaan atau kaula. Warga negara merupakan salah satu syarat mutlak dari suatu negara, disamping dua syarat lainnya yaitu wilayah dan pemerintahan yang berdaulat. Sebagai salah satu syarat berdirinya, warga negara memiliki posisi yang sangat urgent karena selain menjadi syarat juga menjadi promotor untuk menggerakkan arah kebijakan suatu negara. Ia dapat mengisi dalam suatu pemerintahan sekaligus mengatur bagaimana pemanfaatan wilayah yang dikuasai negara. Warga negara memiliki suatu hak dan kewajiban sebagai timbal balik kepedulian terhadap arah kebijakan suatu negara. Hak-hak warga negara biasanya diatur dalam suatu aturan atau konstitusi dalam suatu negara sesuai dengan kesepakatan bersama.

Lantas, warga negara muda merupakan warga negara yang masih mengalami proses masa transisi dari anakanak menuju warga negara dewasa. Dalam hal ini, Budimansyah (2002: 11) menjelaskan bahwa Anak merupakan warga negara hipotetik. Penyebutan sebagai warga negara hipotetik dimaksudkan bahwa anak merupakan warga negara yang "belum jadi" karena masih harus dibina dan didik untuk menjadi warga negara yang dewasa, sadar akan hak dan kewajibannya baik dalam hubungannya dalam bermasyarakat, berbangsa, dan bernegara. Masyarakat masih mendambakan warga negara mudanya menjadi warga negara yang baik dan mampu berpartisipasi dalam kehidupan baik bermasyarakat, berbangsa, dan bernegara. Keinginan tersebut, lebih tepat disebut sebagai perhatian dan kepedulian yang terus tumbuh terutama pada masyarakat yang demokratis.

Berdasarkan uraian mengenai warga negara muda tersebut, maka dapat disimpulkan bahwa warga negara muda merupakan warga negara yang cukup dewasa, yang masih membutuhkan arahan, binaan, dan pendidikan untuk menjadi warga negara dewasa. Secara lebih sederhana warga negara muda dikerucutkan pada warga negara muda yaitu peserta didik di persekolahan. Dengan demikian, penanaman nasionalisme pada warga negara muda di pendidikan formal lebih tepat dilakukan melalui Pendidikan Pancasila dan Kewarganegaraan. Pendidikan Pancasila dan Kewarganegaraan sangat diperlukan guna menuju warga negara yang cerdas (smart) dan baik (good citizenship) sesuai dambaan negaranya.

\section{Kajian Pendidikan Pancasila dan Kewarganegaraan}

Istilah Pendidikan kewarganegaraan berasal dari kata civic education yang berarti pendidikan kewargaan. Kemudian dikembangkan oleh TIM ICCE (Indonesia Center for Civic Education) (2005) dengan istilah Pendidikan Kewarganegaraan. Max A.Hope (2012: 98) menjelaskan bahwa pendidikan kewarganegaraan yang baik perlu mengembangkan pengetahuan dan keterampilan, dan nilai-nilai dalam tiga bidang yang saling terkait meliputi tanggungjawab sosial, moral, keterlibatan masyarakat dan melek politik. Pendidikan kewarganegaraan memainkan peran penting dalam membangun dan mendukung kewarganegaraan bertanggung jawab di negara manapun.

Kerr (1999: 15-16) menjelaskan bahwa pendidikan kewarganegaraan dikonseptualisasikan dalam tiga pendekatan, yaitu pendidikan tentang kewarganegaraan, memusatkan perhatian untuk mempersiapkan para peserta didik dengan pengetahuan dan pemahaman yang cukup tentang sejarah nasional dan kehidupan politik. Pendidikan melalui 
kewarganegaraan, menitikberatkan pada keterlibatan peserta didik untuk belajar melakukan melalui pengalaman-pengalaman untuk aktif, berpartisipasi di sekolah atau masyarakat lokal. Pendidikan untuk kewarganegaraan, mencakup kedua pendekatan yang menitikberatkan pada proses membekali peserta didik dengan seperangkat alat (kognitif) dan disposisi yang memungkinkan untuk berpartisipasi secara aktif. Pendidikan seperti ini menitikberatkan pada pendidikan kewarganegaraan dan keseluruhan pengalaman pendidikan peserta didik.

$$
\text { Selain itu, pendidikan }
$$

kewarganegaraan diberbagai negara belahan dunia juga memiliki tujuan yang beragam. Bromley (2011: 45-47), menyampaikan bahwa perkembangan pendidikan kewarganegaraan di negara Finlandia. Tujuan Pendidikan Kewaeganegaraan memiliki pergeseran pada abad ke dua puluh. Orientasi pendidikan kewarganegaraan pendidikan kewarganegaraan yang awalnya bertujuan untuk kesetiakawanan dan persatuan dalam konteks nasional yang kuat beralih kepada pengunggulan konsep multikultural atau keberagaman. Dengan demikian, bentukan peserta didik lebih kepada kesadaran akan wawasan global. Borhaug (2010: 66-67), menjelaskan mengenai pendidikan kewarganegaraan di negara Norwegia. Pendidikan kewarganegaraan difokuskan pada hal-hal yang konstitusional dan struktur formal lembaga pemerintah. Colceru (2013: 23-24) dalam kajian pendidikan kewarganegaraannya di Rumania menyampaikan bahwa Pendidikan kewarganegaraan di Rumania difokuskan pada pembentukan warga negara yang baik "good citizenship". Pendidikan kewarganegaraan yang dikembangkan di Rumania lebih menuntut pada civic skills dan civic dispotision. Faraouk (2011: 156157) menyodorka mengenai pendidikan kewarganegaraan di Malaysia. Pelaksanaan pendidikan kewarganegaraan di Malaysia didasarkan atas relevansinya dengan demokrasi liberal. Nilai-nilai demokrasi dan norma-norma juga terintegrasi dalam pendidikan kewarganegaran di Malaysia. Orientasi pendidikan kewarganegaraan di Malaysia juga bermuara pada partisipasi warga negara aktif melalui internalisasi nilai-nilai demokrasi. Pentingnya pendidikan kewarganegaraan lebih fokus sebagai alat menuju pembangunan bangsa dan modal sumber daya manusia.

Tiga elemen inti kewarganegaraan sebagai fokus pendidikan kewarganegaraan (PKn) yaitu pengetahuan (knowledge), keterampilan (skill), dan sikap (disposition) yang harus diberikan kepada peserta didik. Lee (2004: 281), menyampaikan pendidikan kewarganegaraan bisa digolongkan dalam tiga point pokok yaitu harmoni, spiritual, dan pengembangan individu atau penanaman diri. Banks dalam Moses (2012: 2) menjelaskan bahwa pendidikan kewarganegaraan harus memiliki tujuan untuk membantu siswa mengembangkan pemahaman tentang saling ketergantungan di antara bangsa-bangsa di dunia modern, mengklarifikasi sikap terhadap negaranegara lain dengan masyarakat dunia. Eyiuche and Lilian (2013: 96) juga menyampaikan bahwa pendidikan kewarganegaraan ditafsirkan secara luas untuk mencakup persiapan warga negara muda untuk berperan dan bertanggungjawab sebagai warga negara. Pendidikan kewarganegaraan yang efektif mengajarkan warga negara muda untuk berpartisipasi aktif dan diharapkan mengalami perubahan kearah positif dalam lingkungan mereka untuk mengembangkan komitmen yang abadi untuk partisipasi di masyarakat.

Pada konteks Indonesia, Pendidikan Kewarganegaraan mengalami perkembangan dan perubahan baik kemasan maupun subtansinya. Hal ini dibuktikan pada kurikulum PKn yang mengalami perubahan sampai saat ini berlaku kurikulum 2013 dengan nama baru Pendidikan Pancasila dan Kewarganegaraan. 
Sedangkan, tujuan dari Pendidikan Pancasila dan Kewarganegaraannya sangat beragam. Berdasarkan Departemen Pendidikan Nasional (2006: 49) PKn memiliki tujuan untuk memberikan kompetensi diantaranya: (1) berpikir kritis, rasional, dan kreatif menanggapi isu kewarganegaraan; (2) berpartisipasi secara cerdas dan bertanggung jawab dalam bertindak di masyarakat, bangsa, dan negara; (3) mengembangkan diri untuk berkarakter Indonesia agar bisa hidup bersama dengan bangsa lain; (4) berinteraksi dengan bangsa lain secara langsung dengan memanfaatkan teknologi, informasi, dan komunikasi. Sedangkan, di sisi lain para ilmuan yang berfokus pada pendidikan kewarganegaraan menyampaikan tujuan pendidikan kewarganegaraan di Indonesia yang beragam. Djahiri (1995: 10) menyampaikan bahwa melalui pendidikan kewarganegaraan peserta didik diharapkan memiliki: (1) pemahaman tentang konsep dan norma Pancasila sebagai falsafah bangsa Indonesia; (2) melek akan konstitusi Negara Republik Indonesia yaitu UUD NRI 1945. Maftuh dan Sapriya (2005: 30) juga menyampaikan tujuan negara yaitu mengembangkan Pendidikan Pancasila dan Kewarganegaraan agar setiap warga negara menjadi warga negara yang baik (to be good citizens) yakni yang cerdas (civic inteliegence) dan tanggung jawab (civics responsibility).

Pendidikan

kewarganegaraan setidaknya harus mengembangkan generasi muda untuk memperoleh pengetahuan, keterampilan, dan sikap yang akan mempersiapkan peserta didik untuk menjadi warga negara yang kompeten dan bertanggung jawab sepanjang hidup. Di Indonesia, seharusnya pendidikan kewarganegaraan memang memiliki titik pangkal pada bagaimana ideologi yang dianut yaitu Pancasila. Seperti dalam simpulan Budiwibowo, (2016: 571), menyebutkan bahwa ditinjau dari definisi filsafat Pancasila merupakan usaha pemikiran. Dengan demikian, tujuan pendidikan kewarganegaraan untuk mempersiapkan warga negara yang pintar dan baik (smart and good citizens) dengan berdasarkan Pancasila sebagai esensi pemikiran.

\section{Reformulasi PPKn Untuk Menguatkan Nasionalisme Warga Negara Muda Di Wilayah Perbatasan}

Pendidikan Pancasila dan Kewarganegaraan merupakan salah satu mata pelajaran yang sangat penting bagi kebanyakan negara dibelahan dunia. Mata pelajaran ini di dalamnya mengandung beberapa muatan politik negara yang diarahkan pada peningkatan rasa nasionalisme dari masing-masing negara. Pendidikan kewarganegaraan pada dasarnya bermuara pada demokrasi politik. Hal ini disebabkan di dalamnya terdapat cakupan tentang ilmu kewarganegaraan yang meliputi pengkajian hak dan kewajiban warga negara. Dengan demikian, pendidikan kewarganeganegaraan (civic education) merupakan suatu upaya untuk mengimplementasikan (ilmu kewarganegaraan) melalui jalur pendidikan (Winarno, 2014: 4).

$$
\text { Pada konteks persekolahan, }
$$
pendidikan kewarganegaraan memiliki kewajiban utama yaitu menjadikan peserta didik sebagai warga negara yang baik dan cerdas (smart and good citizens). Warga negara yang baik merupakan warga negara yang memiliki pemahaman dan kesadaran tentang hak dan kewajibannya sebagai warga negara Indonesia. Margaret Stimman Branson (1999) menyampaikan bahwa terdapat tiga komponen utama yang perlu dipelajari untuk mencapai beberapa tujuan dalam pendidikan kewarganegaraan. Tiga komponen tersebut diantaranya adalah civic knowledge, civic skills, and civic disposition. Berbekal penguasaan yang mengarah pada pengetahuan dan keterampilan sampai menjadi watak kewarganegaraan, maka akan tercipta apa 
yang disebut sebagai civic nationalism dalam diri peserta didik.

Pada konteks modern, nasionalisme

lebih diarahkan pada konsep kesetiaan tertinggi kepada bangsa dan negara. Negara Indonesia sebagai salah satu nation-state telah mengalami beberapa tahap proses perkembangan nasionalisme. Tahap nasionalisme di Indonesia dimulai dari masa kemerdekaan (1900-1945), masa perjuangan mempertahankan kemerdekaan Indoensia (1945-1950), dan masa perjuangan mengisi kemerdekaan Indonesia (1950-sekarang) (Sudiyo, 2004: 14-15). Dengan demikian, saat ini menjadi tugas generasi penerus bangsa untuk mengisi kemerdekaan Indonesia melalui kegiatan-kegiatan positif, berkarya, dan mengabdi untuk negeri. Akan tetapi, pada realitanya masih banyak isu degradasi nasionalisme yang terjadi dibeberapa wilayah perbatasan sebagai wilayah terdepan negara Indonesia. Hal ini dibuktikan dari beberapa penelitian yang memfokuskan pada nasionalisme di wilayah perbatasan Indonesia. Bakker (2012: 297299) melakukan penelitiannya di wilayah perbatasan Indonesia dengan Timur Leste. Hasilnya menyebutkan bahwa seharusnya pembelajaran PKn yang berorientasi pada pembinaan nasionalisme melalui pengembangan model yang lebih menonjolkan nasionalisme pada peserta didik di perbatasaan. Penelitian selanjutnya dilakukan oleh Jantisiana (2016: 133-134) penelitian nasionalisme dilakukan di wilayah perbatasan Indonesia dengan Malaysia. Hasil yang diperoleh adalah adanya suatu ketimpangan tentang fasilitas pendidikan, sehingga mempengaruhi pikiran peserta didik untuk membandingkan fasilitas pendidikan dengan Malaysia. Demikian mempengaruhi pemikiran peserta didik rendahnya nasionalisme dalam peserta didik. Kemudian, penelitian yang dilakukan oleh Dedes (2015: 152) yang memfokuskan penelitiannya di wilayah perbatasan Indonesia-Singapura. Hasil yang didapatkan terjadinya nasionalisme yang terbelah, disatu sisi mengaku sebagai bangsa Indonesia dan disisi lain faktor kemelayuan sebagai raison d'etre menjadikan batas negara seakan semu. Selain itu, efek globalisasi juga mempengaruhi nasionalisme di daerah perbatasan karena mudahnya mobilisasi barang atau jasa bahkan seorang yang memiliki perbedaan kewarganegaraan.

Berdasarkan beberapa data tersebut, menjadi penting adanya reformulasi PPKn dalam rangka meningkatkan nilai-nilai nasionalisme di wilayah perbatasan. Hal ini juga didukung oleh pendapat Banks (2008: 135) yang menyatakan perlunya konsepsi ulang Pendidikan Pancasila dan Kewarganegaraan di abad 21 agar mampu secra efektif mendidik peserta didik untuk menjadi warga negara yang memiliki fungsi. Oleh karena itu, pada abad 21 terminologi Pendidikan Kewarganegaraan harus dimaknai dalam konsep yang luas untuk menghadapi tantangan global (Setiarsih, 2017: 80). Reformulasi pendidikan akan menuai keberhasilan ketika mendasarkan pada pengetahuan transformatif dari pengetahuan yang mainstream. Reformulasi yang dimaksudkan mengarahkan Pendidikan Pancasila dan Kewarganegaraan menjadi salah satu mata pelajaran yang mampu menjadikan peserta didik memiliki apa yang disebut sebagai "Act locally and think globally". Penulis bermaksud menarik istilah "Act locally and think globally" dalam ilmu kewarganegaraan yang dimaknai masih mempertahankan nilai-nilai, budaya, adat asli Indonesia, akan tetapi memiliki cara pandang yang tidak ketinggalan dari kancah internasional.

Pendidikan Pancasila dan Kewarganegaraan sebagai salah satu pendidikan politik, pendidikan demokrasi, dan pendidikan moral dalam lingkup persekolahan, harus mampu memberikan pemahaman yang utuh tentang makna melestarikan nilai-nilai kebangsaan yang berpangkal pada kualitas ke-Indonesiaan. Peserta didik sebagai warga negara muda di 
wilayah perbatasan harus memahami, menyadari, menjadikan muatan hati nurani untuk mencintai dan bertindak nyata dalam mempertahankan dan mengembangkan jati diri yang dilandasari nilai ke-Indonesiaan yaitu Pancasila, UUD NRI 1945, NKRI, dan Bhinneka Tunggal Ika (Slamet, 2016: 4). Di sinilah prinsip "act locally" akan berperan sebagai filterisasi pada tingkah-laku peserta didik dalam menyikapi beberapa pengaruh budaya asing yang masuk. Selain itu, prinsip "think globally" menjadi sebuah unsur untuk mengikuti isu global dengan analisis yang bermuara pada nilai-nilai lokal. Dengan kata lain, Pendidikan Pancasila dan Kewarganegaraan harus mengembangkan peserta didik untuk mampu melestarikan nilai-nilai luhur bangsa Indonesia (daya preservatif) dan sekaligus mengembangkan daya progresif melalui gesekan-gesekan yang positif dengan kemajuan-kemajuan negara lain yang dilakukan secara eklektifinkorporatif (memilah dan memilih nilainilai yang sesuai dengan jati diri keIndonesiaan) agar tidak menimbulkan konflik atau benturan antarnilai. Dengan reformulasi Pendidikan Pancasila dan Kewarganegaraan yang menekankan pada prinsip "act locally and think globally" diharapkan dapat menguatkan nasionalisme peserta didik di wilayah perbatasan.

\section{SIMPULAN DAN SARAN Simpulan}

Reformulasi Pendidikan Pancasila dan Kewarganegaraan dimaksudkan untuk mengarahkan peserta didik untuk memiliki kompetensi yang disebut sebagai "Act locally and think globally". Kompetensi yang dapat melestarikan dan mempertahankan nilai-nilai, budaya, adat asli Indonesia, akan tetapi memiliki cara pandang global mengikuti perkembangan dunia internasional. Pendidikan Pancasila dan Kewarganegaraan sebagai pendidikan politik, pendidikan demokrasi, dan pendidikan moral dalam lingkup persekolahan harus mampu memberikan pemahaman yang utuh tentang makna melestarikan nilai-nilai kebangsaan yang berpangkal pada kualitas ke-Indonesiaan.

Peserta didik sebagai warga negara negara muda di wilayah perbatasan harus memahami, menyadari, menjadikan muatan hati nurani wajib mencintai dan bertindak nyata dalam mempertahankan dan mengembangkan jati diri berdasarkan nilai ke-Indonesiaan yaitu Pancasila, UUD NRI 1945, NKRI, dan Bhinneka Tunggal Ika. Dengan demikian, Pendidikan Pancasila dan Kewarganegaraan harus mengembangkan kompetensi peserta didik agar mampu melestarikan nilai-nilai luhur bangsa Indonesia (daya preservatif) sekaligus mengembangkan daya profresif yang dilakukan secara eklektif-inkorporatif sebagai filterisasi budaya asing agar tidak berbenturan. Melalui reformulasi Pendidikan Pancasila dan Kewarganegaraan diharapkan mendorong penguatatan nasionalisme warga negara muda di wilayah perbatasan.

\section{Saran}

Nasionalisme dalam warga negara muda di wilayah perbatasan sangat penting untuk memperkokoh persatuan dan keutuhan Negara Kesatuan Republik Indonesia. Pendidikan Pancaila dan Kewarganegaraan harus diarahkan pada muatan pemahaman secara holistik tentang pentingnya melestarikan nilai-nilai lokal sekaligus mengarahkan peserta didik untuk memiliki cara pandang global agar mampu bersaing di kancah internastional.

\section{DAFTAR PUSTAKA}

Aman. (2011). Model Evaluasi Pembelajaran Sejarah. Yogyakarta: Ombak

Anderson, B. (1999). Imagined Communities: Reflections on the Origin and Spread of Nationalism. London: Verso 
Bakker, R. (2012). Pembinaan Nasionalisme Generasi Muda Di Wilayah Perbatasan Indonesia Dengan Timor Leste Melalui Pendidikan Kewarganegaraan. Diunduh pada 30 April 2017 dari Repository.upi.edu

Banks, J.A. (2008). Diversity, Group Identity, and Citizenship Education in a Global Age. Educational Researcher, 37 (3), 129-139.

Borhaug, Kjetil. (2010). Norwegian Civic Education - Beyond Formalism? L Education Civique Norvegienne - Au -dela du Formalisme? Journal of Social Science Education. 9 (1), 66-67

Branson, N. S. (1999). (Terjemahan Syaripudin, dkk). Belajar "Civic Education" dari Amerika. Yogyakarta: Lembaga Kajian Islam dan Sosial (LKIS)

Bromley, Patricia,. dan Elina Makinen. (2011). Diversity in Civic Education: Finland in Historical and Comparative Perspective. Journal of International Cooperation in Education. 14 (2), 4547

Brubaker, R. (2004). In the Name Of the Nation: Reflections on Nationalism and Patriotism. Citizenship Studies. 8 (2), 116

Budiawan. (2017). Nasion \& Nasionalisme: Jelajah Ringkas Teoretis. Yogyakarta: Ombak

Budiman, J. (2010). Permasalahan Etnis Tionghoa. Sumber: http://kompasiana.com (Diunduh 10 November 2017)

Budimansyah, D. (2002). Model Pembelajaran dan Penilaian. Bandung: Remaja Rosda Jarya
Budiwibowo, S. (2016). Revitalisasi Pancasila dan Bela Negara dalam Menghadapi Tantangan Global Melalui Pembelajaran Berbasis Multikultural. Citizenship: Jurnal Pancasila dan Kewarganegaraan, 4 (2): 565-585.

Colceru, Emilian. (2013). The Impact of Civic Education on the Citizenship of Romanian Youth. Journal of Social Science Education. 12 (4): 23-24

Darmaputra, R. (2009). Manajemen Perbatasan dan Reformasi Sektor Keamanan. Jakarta: Institute for Defense Scurity and Peace Studies (IDSPS)

Dedees, A. R. (2015). Melayu Di Atas Tiga Bendera: Kontribusi Identitas Nasionalisme Masyarakat Perbatasan Di Kepulauan Batam. Jurnal Ilmu Sosial dan Ilmu Politik. 19 (2), 141 152

Departemen Pendidikan Nasional. (2006). Kurikulum Tingkat Satuan Pendidikan. Jakarta: Depdiknas

Djahiri, A. K. (1995). Dasar-dasar Umum Metodologi dan Pelajaran Nilai dan Moral PVCT. Purwakarta: IKIP

Eyiuche, I. O., and Lilian, R. A. (2013). Toward a Function Citizenship Education Curriculum in Nigeria Colleges of Education for Sustainable Development in the 21st Century. American International Journal of Contemporary Research. 3 (8), 96-102

Farouk, Azeem AF., dan Azrina Husin. (2011). Civic Education in an Emerging Democracry: Students'Experiences in Malaysia's Projek Warga. Asian Social Science. 7 (3): $156-157$ 
Citizenship Jurnal Pancasila dan Kewarganegaraan Vol 6 No 1 April 2018, hal 1-16

Avaliable online at : http://e-journal.unipma.ac.id/index.php/citizenship

ISSN: 2302-433X (print) 2579-5740 (online)

Gidden, A. (1985). The Nation-State and Violence. Berkeley \& Los Angeles: University of California Press

Hutchinson, J. \& Smith, A. D. (eds) (1994). Nationalism. Ixfoerd \& New York: Oxford University Press

Hutchinson, J., \& Smith, A. D. (eds) (1994). Nationalism, Oxford \& New York: Oxford University Press.

Jantisiana, N. M. (2016). Pandangan Nasionalisme Siswa SMA Di Wilayah Perbatasan Indonesia-Malaysia Dalam Mata Pelajaran Sejarah. Diunduh pada 30 April 2017 dari Repository.upi.edu

Keith, B., \& Shane, O. (2010). After nation? Critical Reflection on Nationalism and Postnationalism. Palgrave Macmilan: New York

Kerr, D. (1999). Citizenship: Local, National, and International. The Taylor \& Francis e-Library, 2 (7), 1516

Kitromilides, P. M. (2005). Elie Kedourie's Contribution to the Study of Nationalism. Middle Eastern Studies. $41(5)$

Lee. W. O., \& Grossman, D. L. (Eds). (2004) Citizenship Education In Asia And The Pasific Concepts And Issuse. Hongkong: The Unisersity of Hong Kong Pokfulam.

Maftuh dan Sapriya. (2005). Implementasi KBK Pendidikan Kewarganegaraan dalam Berbagai Konteks. Jurnal Civicus; 319-328

Max A. H. (2012). Becoming citizens through school experience: A case study of democracy in practice.
International Journal pf Progressive Education, Vol.8 No.3: 94-108

Moses, C. (2012). Civic Education and Global Citizenship: A Deweyan Perspective. Journal of Peace Education and Social Justice. 6 (1), 125

Munawaroh, S. (2015). Nasionalisme Melalui Pendidikan Agama Pada Peserta Didik SMA/SMK/MA di Wilayah Perbatasan Kalimantan Barat. Jurnal Smart. 1 (2)

Novita, I. R. (2014). Penanaman Nilai Nasionalisme Dan Patriotisme Untuk Mewujudkan Pendidikan Karakter Pada Mata Pelajaran Pendidikan Kewarganegaraan Siswa Kelas X SMA Negeri 4 Sidoarjo. Kajian Moral dan Kewarganegaraan, 1 (1)

Peraturan Pemerintah Nomor 12 Tahun 2010 tentang Badan Nasional Pengelola Perbatasan (BNPP).

Poetranto T. (2008). Strategi Penanganan Wilayah Perbatasan. Buletin Puslitbang Strahan Balitbang Dephan, 4-6

Slamet P. H. (2016). Model Pembelajaran Inovatif Berbasis Kespesifikan Lokal. Sumber: Seminar Nasional tentang Kearifan Lokal (UPY, 2016)

Snyder, L.L. (1954). The Meaning of Nationalism. New Jersey: Rutgers University Press.

Sudiyo. (2004). Pergerakan Nasional Mencapai \& Mempertahankan Kemerdekaan. Jakarta: Rineka Cipta

Syarbaini, S. (2010). Implementasi Pancasila Melalui Pendidikan Kewarganegaraan. Yogyakarta: Graha Ilmu 
Citizenship Jurnal Pancasila dan Kewarganegaraan Vol 6 No 1 April 2018, hal 1-16

Avaliable online at : http://e-journal.unipma.ac.id/index.php/citizenship ISSN: 2302-433X (print) 2579-5740 (online)

Tijan. (2009). Kewarganegaraan Republik Indonesia. Semarang: Unnes

Tim ICCE UIN. (2003). Demokrasi, Hak Asasi Manusia, Masyarakat Madani (Edisi Revisi). Jakarta: Prenada Media.

TIM ICCE UIN. (2005). Demokrasi, Hak Asasi Manusia, dan Masyarakat Madani. Jakarta: Prenada Media.

Trisandi, R. A. (2013). Peran Guru Sejarah Dalam Meningkatkan Sikap Nasionalisme Siswa Kelas XI IPS SMA Negeri 3 Slawi Tahun Ajaran 2012/2013. Universitas Negeri Semarang, Semarang

Undang-Undang Nomor 20 Tahun 2003 tentang Sistem Pendidikan Nasional
Undang-undang Nomor 43 Tahun 2008 tentang Wilayah Negara

Winarno. 2014. Pembelajaran Pendidikan Kewarganegaraan. Jakarta: Bumi Aksara

Zarbaliyev, H. (2016). Multikulturalisme Di Era Globalisasi: Sejarah Dan Tantangannya Bagi Indonesia. Sumber: Kuliah Umum UNY (15 Maret 2017)

Zed, M. (2004). Metode Penelitian Kepustakaan. Jakarta: PT Raja Grafindo Persada. 